\title{
Processing of ingested dimethylsulfoniopropionate by mussels Mytilus edulis and scallops Argopecten irradians
}

\author{
Richard W. Hill ${ }^{1, *}$, John W. H. Dacey ${ }^{2}$ \\ ${ }^{1}$ Department of Zoology, 203 Natural Science Building, Michigan State University, East Lansing, Michigan 48824, USA \\ ${ }^{2}$ Department of Biology, Woods Hole Oceanographic Institution, Woods Hole, Massachusetts 02543, USA
}

\begin{abstract}
Dimethylsulfoniopropionate (DMSP) synthesized by marine phytoplankton is the principal source of dimethylsulfide (DMS), an important climate-affecting gas. Grazing by small zooplankton on phytoplankton often accelerates DMS production from algal DMSP. The effects of grazing by benthic suspension feeders, such as bivalve molluscs, however, have not been studied, even though their populations sometimes process a sizable fraction of local phytoplankton production. We fed Tetraselmis sp. Strain UW474 (27 to $42 \mathrm{fmol} \mathrm{DMSP} \mathrm{cell}{ }^{-1}$ ) to adult mussels Mytilus edulis and scallops Argopecten irradians and studied the fate of the algal DMSP during the $24 \mathrm{~h}$ following ingestion. Almost none of the ingested DMSP reappeared in the environment as DMS or DMSP; the amount that appeared in the ambient water as DMS was $<1 \%$ of that ingested, and the sum total that appeared either as fecal DMSP (which microbes might convert to DMS) or in the water as DMS or DMSP was $\leq 3$ to $4 \%$ of that ingested. In the short term, therefore, thriving bivalve populations probably strongly reduce the rate of DMS formation (direct or indirect) from local algal DMSP, in contrast to zooplankton populations. Ingested DMSP is likely accumulated in the bodies of mussels and scallops. However, although we have weak evidence of partial accumulation in scallop gastrointestinal tissue, we were unable to document accumulation in mussels because of high variability and statistical nonnormality in their naturally occurring DMSP content. In total, we showed that in the $24 \mathrm{~h}$ following feeding, mussels and scallops do not facilitate ambient DMS formation from algal DMSP and evidently sequester most of the algal DMSP they ingest.
\end{abstract}

KEY WORDS: Dimethylsulfide $\cdot$ DMS $\cdot$ Dimethylsulfoniopropionate $\cdot$ DMSP $\cdot$ Bivalves $\cdot$ Mussels Scallops $\cdot$ Mytilus edulis $\cdot$ Argopecten irradians $\cdot$ Phytoplanktivory

Resale or republication not permitted without written consent of the publisher

\section{INTRODUCTION}

Dimethylsulfoniopropionate (DMSP) synthesized by marine algae is the ultimate source of over half the nonanthropogenic gaseous sulfur flux to the atmosphere (Bates et al. 1992). Atmospheric sulfur flux is of interest because sulfur gases are believed to play major roles in global climate. Although DMSP itself is not volatile, dimethylsulfide (DMS) - one of its breakdown products - is a water-soluble gas which when produced in the surface waters of the oceans, can outgas to the atmosphere. Atmospheric DMS is oxidized to aerosol particulates, including cloud condensation nuclei that affect oceanic cloud cover and thus Earth's reflectivity (albedo) to incoming solar radiation (Andreae \& Crutzen 1997, Malin \& Kirst 1997).

The conversion of algal DMSP to DMS is mediated by biological processes, including microbial DMSP metabolism (Yoch 2002), viral lysis of phytoplankton cells (Hill et al. 1998), and grazing by animals. Dacey \& Wakeham (1986) first introduced the concept that animal grazing on phytoplankton affects the dynamics of DMS production by demonstrating that feeding by copepods on dinoflagellates in laboratory cultures 
accelerated (>20-fold) the formation of DMS from algal DMSP. Subsequent investigations of grazing effects on DMS formation from algal DMSP have employed laboratory systems to study other predator-prey relations or have sought evidence in natural waters, such as correlations between DMS concentration and grazer density (e.g. Leck et al. 1990, Archer et al. 2003). Zooplankton implicated in accelerating DMS production - thereby tending to increase the DMS concentration in sea surface waters and force a greater flux of DMS to the atmosphere-include copepods (Dacey \& Wakeham 1986, Lee et al. 2003), krill (Daly \& DiTullio 1996, Kasamatsu et al. 2004), and microzooplankton (Archer et al. 2003). On the other hand, grazing by menhaden (Hill \& Dacey 2006) or salps (Kasamatsu et al. 2004) does not accelerate DMS production, at least in the short term. The effects of feeding by benthic suspension feeders have not previously been investigated.

We report here on the processing of algal DMSP by adults of 2 species of bivalve molluscs, the blue mussel Mytilus edulis and the bay scallop Argopecten irradians. We chose these species in part because they are relatively divergent in the ways they employ the basic bivalve feeding mechanism to remove phytoplankton from the water: whereas mussels (for example) employ well-developed laterofrontal cirri, scallops lack such cirri (Jørgensen 1990).

An important reason for studying bivalves is that populations of some species can be sufficiently dense to exert a major controlling influence on local ecosystems and process a sizable fraction of local phytoplankton production (Newell 1988, Jørgensen 1990, Riisgård 1991, Heip et al. 1995, Dame 1996). These attributes are especially true of mussel and oyster populations because of the high local densities they often attain, and one reason we chose Mytilus edulis for study was that it is particularly well known for its dense populations. Although Argopecten irradians populations reach densities of 70 scallops $\mathrm{m}^{-2}$ (Shumway 1991), M. edulis populations often consist of hundreds of mussels m ${ }^{-2}$ (Riisgård 1991). Riisgård (1991) calculated that a population of $M$. edulis in Limfjord (Denmark) filtered $180 \mathrm{~m}^{3}$ of ambient water $\mathrm{m}^{-2} \mathrm{~d}^{-1}$, a rate equivalent to 20 times the local water column $\mathrm{d}^{-1}$. Jørgensen (1990) concluded that processing of ca. $240 \mathrm{~m}^{3} \mathrm{~m}^{-2} \mathrm{~d}^{-1}$ is typical for $M$. edulis beds. Bivalve populations dominated by $M$. edulis in parts of the Wadden Sea are able to clear all phytoplankton from the entire local volume of water in 2 to $5 \mathrm{~d}$, and they harvest from 18 to $>100 \%$ of local phytoplankton production (Dame 1996). Such estimates suggest that in places like the Wadden Sea, 18 to $>100 \%$ of local algal DMSP production may be processed first by mussels.

The species of mussels and other bivalves that exist today in populations dense enough to exert significant ecosystem effects occur principally in relatively shallow habitats in temperate and near-temperate parts of the globe (Dame 1996). These localized settings which, from a global perspective, are of modest extent - are therefore the context in which bivalves could play major roles in the processing of phytoplankton DMSP; bivalves would not be significant in oceanic DMSP processing. Despite the localized nature of likely bivalve effects, the effects deserve elucidation not just because they may be locally major, as already stressed, but also because studies of ecosystem-scale DMSP processing have often been carried out in the very sorts of settings where extensive bivalve beds can occur. Important studies of DMSP and DMSP processing at ecosystem scales have been conducted, for example, in the Delaware and Chesapeake Bays (Iverson et al. 1989), Long Island Sound (Tang et al. 2000b), and the coastal Baltic (Leck et al. 1990) and North (Archer et al. 2003) Seas. In future studies of ecosystem-scale DMSP processing in locales like these, it will be desirable to have information on the possible effects of bivalve beds.

The potential of bivalves to play major roles in the processing of phytoplankton DMSP rests not only on their population densities but also on their abilities as individuals to pump water at impressively high rates through their feeding apparatus and efficiently remove wide size ranges of particulate matter from the water they pump. At temperatures near 10 to $20^{\circ} \mathrm{C}$, roughly speaking (not focusing in detail on the current debate over proper measurement of pumping rates), individual Mytilus edulis of the size we studied $(\sim 6.5 \mathrm{~cm}$ shell height) pump water at 10 to $20 \mathrm{l} \mathrm{h}^{-1}$ through their feeding apparatus when feeding (Møhlenberg \& Riisgård 1979, Riisgård 2001, Petersen et al. 2004), while individual Argopecten irradians ( 5 cm) pump 4 to $10 \mathrm{l} \mathrm{h}^{-1}$ (Chipman \& Hopkins 1954). M. edulis is one of the most effective bivalves at retaining small cells from the water it processes; it completely retains $4 \mu \mathrm{m}$ particles, retains $90 \%$ of $3 \mu \mathrm{m}$ particles, and $50 \%$ of $1 \mu \mathrm{m}$ particles (Jørgensen 1990). Equally important, M. edulis ingests cells spanning the full natural size range of phytoplankton, including cells exceeding $100 \mu \mathrm{m}$ (Asmus \& Asmus 1993). With this breadth of diet, mussel beds seem certain to consume a great diversity of DMSP-synthesizing algal species (Keller et al. 1989). A. irradians fully retains $5 \mu \mathrm{m}$ particles, retains $90 \%$ of $4 \mu \mathrm{m}$ particles, and $50 \%$ of $2.5 \mu \mathrm{m}$ particles (Jørgensen 1990).

Beside the potential of bivalve populations to ingest large fractions of local DMSP production, a second way in which such populations may be major players in ecosystem DMSP processing arises from the emerging paradigm that bivalves (including mussels and scallops) can be significant consumers of zooplankton 
(Lehane \& Davenport 2002, Wong \& Levinton 2006). By depleting zooplankton populations, bivalve populations may reduce the importance of zooplankton DMSP processing (Dacey \& Wakeham 1986, Archer et al. 2003, Lee et al. 2003) while simultaneously enhancing the importance of their own DMSP processing. This perspective emphasizes the importance of learning how bivalve DMSP processing resembles and differs from that of other phytoplanktivores.

Our goal was to elucidate the fate of phytoplankton DMSP in the first $24 \mathrm{~h}$ after adult mussels and scallops feed. In choosing the phytoplankter for our studies, we emphasized existing knowledge of the palatability and nutritional adequacy of phytoplankton for bivalves. We chose the prasinophyte Tetraselmis sp. because it not only synthesizes DMSP but also is (1) fully retained by feeding bivalves (Møhlenberg \& Riisgård 1979), (2) known to support growth of Mytilus edulis (Strömgren \& Cary 1984), (3) assimilated to a large extent (69 to $84 \%$ ) by adult M. edulis (Winter 1978) and Argopecten irradians (Peirson 1983), and (4) commonly chosen as food for both species in aquaculture and experiments. We found that in the first $24 \mathrm{~h}$ following feeding, mussels and scallops do not accelerate formation of ambient DMS from DMSP they ingest, and they do not return DMSP to the environment where ambient microbes might metabolize it to form DMS.

\section{MATERIALS AND METHODS}

Mussels Mytilus edulis, measuring 5.5 to $8.1 \mathrm{~cm}$ shell height (we follow the morphological terminology of Gosling 2003), and scallops Argopecten irradians, 5.0 to $7.2 \mathrm{~cm}$, were collected offshore from Woods Hole, Massachusetts, USA, in winter, 1 to 2 mo prior to study. They were maintained in running seawater from Vineyard Sound (31 to $33 \mathrm{ppt}$ salinity, $\sim 0.3 \mathrm{nmol} \mathrm{l}^{-1}$ particulate DMSP). Initially the water was unheated $\left(\sim 2^{\circ} \mathrm{C}\right)$. During the study, the water temperature was 17 to $19^{\circ} \mathrm{C}$ for the mussels and 14 to $15^{\circ} \mathrm{C}$ for the scallops. The bivalves' ambient temperature was raised to these levels gradually over 10 to $20 \mathrm{~d}$. The shells of all bivalves were brushed to remove fouling organisms. During the study we monitored the exchanges of particulate DMSP (DMSPp), dissolved DMSP (DMSPd), and DMS between the bivalves and the ambient water, the elimination of DMSP in feces, and the accumulation of DMSP in tissue.

The bivalve chambers employed were $3.8 \mathrm{l}$, glass, wide-mouth, screw-top jars (metal lids), each containing 21 of seawater that had been passed through Gelman A/E glass fiber filters (nominal pore size $1 \mu \mathrm{m}$ ). To seal a jar, the glass threads were wrapped with Teflon plumbing tape prior to applying the lid, then vinyl electrical tape was wrapped around the seam between the lip of the lid and the walls of the jar. Gentle aeration of the water in the sealed jar at $60 \mathrm{ml} \mathrm{min}^{-1}$ was achieved with an external peristaltic pump (Harvard Apparatus) that drew gas from the headspace in the jar and delivered it to a submerged bubbling stone. Aeration was only occasional to minimize disturbance of the bivalves. Tubing for the aeration loop passed through 2 gas-tight ports in the lid of the jar. Two additional ports permitted access to (1) the headspace to remove gas or add $\mathrm{O}_{2}$ and (2) the water in the jar to withdraw water samples or add food. All tubing was glass except for minimal lengths of food-grade Tygon tubing used as flexible joints and as peristaltic tubing in the pump. Jars were isolated from outside disturbances because bivalves are sensitive to environmental changes (Riisgård \& Møhlenberg 1979).

The capacity of the study chambers to retain DMS was assessed in 2 preliminary tests in which chambers containing 21 of seawater, with aeration systems operating, were injected with pure DMS (Fluka) to bring the water concentration to $300 \mathrm{nM}$. In the first test, employing filtered seawater like that used in experiments, the DMS concentration remained at $100 \%$ of the initial concentration for $3.5 \mathrm{~h}$, fell to $94-99 \%$ after $19 \mathrm{~h}$, and $88-96 \%$ after $26 \mathrm{~h}$, demonstrating that there was little DMS leakage and/or little destruction by microbes in the water used. In the second test, employing sterile seawater, the DMS concentration remained at $100 \%$ of the original for $26 \mathrm{~h}$, demonstrating that leakage was zero. Some researchers believe that absorption or adsorption of small quantities of DMS by glass can introduce errors. To test for this sort of problem, we coated jars with the syliating agent Prosil-28 (PCR) and compared them with ordinary jars, each sealed jar containing sterile seawater with $240 \mathrm{nM}$ DMS. For $5 \mathrm{~h}$, no change occurred in the DMS concentration in either type of jar. Accordingly, we used ordinary, untreated jars.

The Tetraselmis sp. used for food was a culture (not axenic) of Strain UW474, which is referable to T. chuii or T. suecica (R. A. Lewin, pers. comm.). Average DMSP content at the stage of use was 27 to $42 \mathrm{fmol}$ $\mathrm{cell}^{-1}$, and average cell dimension was $9 \times 14 \mu \mathrm{m}$. The algae were grown to a density of 6 to $14 \times 10^{5} \mathrm{cells} \mathrm{ml}^{-1}$ (counted by hemacytometer) in autoclaved $\mathrm{f} / 2$ medium in glass carboys at $20^{\circ} \mathrm{C}$ with steady illumination from banks of fluorescent bulbs.

Pseudofeces production was a concern because algal cells incorporated into pseudofeces, although removed from the water, are not ingested and not available for ingestion (pseudofeces are macroscopic clumps of uneaten material assembled by and ejected from bivalves; palatable algal cells when excessively concentrated in the ambient water are sometimes included). 
Our strategy to prevent pseudofeces production was to keep the algal cell density in the animals' ambient water at $\leq 1 \times 10^{7}$ cells $1^{-1}$ during feeding by adding algal culture in multiple aliquots spaced at sufficiently long time intervals to allow the bivalves to clear each aliquot before the next was added. The literature on Mytilus edulis is unambiguous: pseudofeces production starts only at algal cell densities $>1 \times$

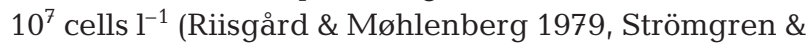
Cary 1984, Riisgård 1991). Because the literature on Argopecten irradians (Palmer \& Williams 1980, Peirson 1983 ) is less conclusive, we repeatedly observed scal-

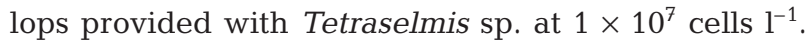
We saw no production of pseudofeces, and no behaviors (e.g. valve clapping) ordinarily associated with pseudofeces production.

Four identical chambers were studied simultaneously in the work on each species. Three contained bivalves: 5 randomly selected individuals chamber ${ }^{-1}$ in the mussel study, or 2 individuals chamber ${ }^{-1}$ in the scallop study. The fourth chamber (the control) contained no bivalves. Food was added to, and water samples were removed from, all 4 chambers on an identical schedule.

Bivalves were placed in the chambers $5 \mathrm{~d}$ before the study began, and their water was changed once daily thereafter (greatly limiting access to food). On the day before the study and the day of the study itself, the water had been passed through Gelman A/E glass fiber filters. Chambers were sealed 2.5 to $3.8 \mathrm{~h}$ prior to addition of algal culture. The amount of algal culture initially added to each of the 4 chambers was calculated to bring the ambient cell density to $1 \times 10^{7}$ cells $\mathrm{l}^{-1}$. A similar or smaller amount of culture was added to each chamber on 4 to 5 further occasions at intervals of 27 to $45 \mathrm{~min}$. The total amount of algal DMSP added per chamber was calculated from measures of both the DMSPp in the culture added and the DMSPp concentration in the control at the end of feeding.

Water samples were withdrawn twice from each chamber during the period preceding the addition of algal culture. Water samples were then taken periodically for ca. $24 \mathrm{~h}$ after all the algal culture had been added. The samples were withdrawn through a glass sampling tube (tip positioned at mid-depth in the chamber water) by use of a Hamilton $50 \mathrm{ml}$ gas-tight syringe.

Each water sample $(30 \mathrm{ml})$ was drawn under slight vacuum through a $25 \mathrm{~mm}$-diameter Gelman A/E glass fiber filter supported on the fritted glass platform of a glass filter holder, and the filtrate was collected directly into a syliated (Prosil-28) glass vial $(38 \mathrm{ml}$ total volume) sealed with a Teflon-coated butyl rubber septum (Regis). Incubation in base converts DMSP to DMS (Dacey \& Blough 1987). For measure- ment of DMSPp, the filter was placed in $25 \mathrm{ml}$ of $1 \mathrm{~N}$ potassium hydroxide $(\mathrm{KOH})$ in a sealed glass vial. The concentration of DMS in the vial headspace was later measured by sulfur-specific gas chromatography employing a Chromosil 330 (Supelco) column at $54^{\circ} \mathrm{C}$, Sievers 350B sulfur chemiluminescence detector, and Hewlett-Packard 3390A integrator. DMS dissolved in the ambient water was measured by sparging a subsample of the filtrate with nitrogen, cryotrapping effluent DMS on cold $\left(-15^{\circ} \mathrm{C}\right)$ Tenax-GC (Alltech), and heating the Tenax to desorb the DMS for measurement as already specified. DMSPd was measured by bringing the remaining filtrate to a concentration of $1 \mathrm{~N} \mathrm{KOH}$ by addition of $8 \mathrm{~N} \mathrm{KOH}$ in a sealed glass vial to convert DMSPd to DMS, measuring the DMS by headspace analysis, and subtracting preexisting (native) DMS. Standards for all assays were prepared using reagent DMS (Fluka) in background solutions that matched unknowns (e.g. DMS- and DMSP-free seawater containing $1 \mathrm{~N} \mathrm{KOH}$ for standards for DMSPd measurement).

Pure $\mathrm{O}_{2}$ was added to the headspace of each bivalvecontaining chamber to replace $\mathrm{O}_{2}$ used by the bivalves. The average rate of addition for Mytilus edulis was $1.6 \mathrm{ml} \mathrm{O}_{2} \mathrm{~g}^{-1}$ estimated dry flesh weight $\mathrm{h}^{-1}$ during the first $6 \mathrm{~h}$ after feeding and $0.9 \mathrm{ml} \mathrm{g}^{-1} \mathrm{~h}^{-1}$ thereafter (calculated from Bayne et al. 1973, Widdows 1973). For Argopecten irradians (studied at a lower temperature), the average rate of addition was $0.4 \mathrm{ml} \mathrm{O}_{2} \mathrm{~g}^{-1} \mathrm{~h}^{-1}$ at all times (calculated from Bricelj et al. 1987); the rise in metabolic rate during feeding in scallops has rarely been estimated, in part because some studies indicate that feeding does not increase scallop metabolic rates (Shumway 1991).

At ca. $24 \mathrm{~h}$ after the final addition of algae, bivalves were removed, and all fecal matter was vacuumed off the bottom of each chamber by siphoning. Siphon water (430 to $570 \mathrm{ml}$ from mussel chambers, 130 to $240 \mathrm{ml}$ from scallop chambers) was filtered through Gelman A/E glass fiber filters, and the filters (2 to 5 chamber $^{-1}$ ) were incubated in $1 \mathrm{~N} \mathrm{KOH}$ in glass vials to convert fecal DMSP to DMS measured by headspace analysis. Tests with fish feces (Hill \& Dacey 2006) indicate that the presence of fecal matter does not interfere with measurement calibration.

Each mussel from the mussel-containing chambers, plus each of 5 mussels from the same source population that had been treated identically but not fed, was then dissected into 2 parts: (1) the dark-colored digestive gland (consisting of the stomach, digestive diverticula, and associated tissue), and (2) the rest of the body, including mantle, gills, nephridia, and adductor muscles. The scallops that had been in the chambers plus 6 unfed scallops were also dissected into 2 parts: (1) the digestive gland, visceral mass, and (tiny) foot, and (2) the 
rest of the body. We wanted to minimize the potential loss of DMS to the atmosphere during tissue processing. Part 1 of each species was so soft that we were able to subsample it quickly $(<40 \mathrm{~s})$ with scissors; we first minced the whole piece of tissue into small pieces, then mixed the pieces, before taking a subsample. Part 2 had to be processed differently because of the toughness of some of the body parts included, especially the adductor muscle. Part 2 was frozen by being dropped into liquid nitrogen, powdered with mortar and pestle while being kept frozen by additions of liquid nitrogen, and then subsampled while frozen. Each subsample was placed in $25 \mathrm{ml}$ of $1 \mathrm{~N} \mathrm{KOH}$ in a sealed glass vial and headspace gas later assayed for DMS.

To ensure the suitability of our procedure for analyzing tissue DMSP, we carried out 2 checks. One focused on whether the $\mathrm{pH}$ in the glass vials was high enough despite buffering by tissue constituents. Subsamples of mussel tissue homogenate were found to have the same DMSP concentration whether placed in 1 , 2, or $3 \mathrm{~N} \mathrm{KOH}$, indicating that $1 \mathrm{~N} \mathrm{KOH}$ was satisfactory. Our second check focused on whether the presence of tissue affected measurement calibration. When we added defined quantities of both reagent DMS and mussel tissue homogenate to a vial of $1 \mathrm{~N} \mathrm{KOH}$, we found that the measured DMS concentration was identical to the sum of the concentrations measured in 2 vials to which had been added, respectively, matched quantities of only reagent DMS or only homogenate, indicating that the presence of mussel tissue did not interfere with DMS quantification.

\section{RESULTS}

The total amount of algal DMSP fed was $3770 \mathrm{nmol} \mathrm{chamber}^{-1}$ in the mussel chambers and $4470 \mathrm{nmol}$ chamber $^{-1}$ in the scallop chambers. During addition of the algal culture most mussels exhibited behaviors correlated with high feeding rates: open valves, plus extended siphons and/or mantle edges (Møhlenberg \& Riisgård 1979). The scallops held their valves open and had extended mantle edges. Both species visibly cleared the water between aliquots of algal culture. When we refer henceforth to the period of feeding and the end of feeding, we consider feeding to have ended when the bivalves cleared the water for the final time, nominally $30 \mathrm{~min}$ after addition of the last culture aliquot. The mussel and scallop studies continued for 25 and $23.5 \mathrm{~h}$ after feeding ended, respectively.

When the concentration of DMSPp was first measured following the end of feeding, it was 0 (i.e. below the DMSPp detection limit of $20 \mathrm{nmol}$ chamber $^{-1}$, see legend of Table 1) in all 3 of the chambers that contained mussels, and it was only slightly above the detection limit in the scallop chambers, averaging only 37 nmol chamber ${ }^{-1}$ (Table 1; inexplicably, average DMSPp in the scallop chambers rose to $103 \mathrm{nmol}$ chamber $^{-1}$ at $4 \mathrm{~h}$ after feeding, before later falling to 0 ). We observed no pseudofeces production. Thus, the bivalves promptly ingested most or all of the algal DMSP provided (the DMSPp concentration would

Table 1. Mytilus edulis and Argopecten irradians. Quantities of dimethylsulfide (DMS) and dimethylsulfoniopropionate (DMSP) in the water (mean, range in parentheses, for chambers that contained bivalves). Control chambers contained no bivalves. Soon after feeding ended: values measured in bivalvecontaining chambers 30 to 35 min after, and in control chambers 10 to $12 \mathrm{~min}$ after last aliquot of algal culture was added. Water samples were taken 5 times (mussel studies) or 6 times (scallop studies) in period following end of feeding. Max. after feeding ended: highest values observed in any of these 5 or 6 samples; all scallop-containing chambers exhibited maximum DMSPp $4 \mathrm{~h}$ after feeding ended. nm: DMSPp in control chambers at end of study was not meaningful because algal cells settled. Nominal detection limits were $2 \mathrm{nmol}$ chamber $^{-1}$ for DMS, and $20 \mathrm{nmol}$ chamber $^{-1}$ for DMS + dissolved DMSP (DMSPd) and for particulate DMSP (DMSPp)

\begin{tabular}{|c|c|c|c|}
\hline & \multicolumn{3}{|c|}{$\begin{array}{l}\text { Total amount in ambient water } \\
\left(\mathrm{nmol} \text { chamber }^{-1}\right) \text { of: }\end{array}$} \\
\hline & DMS & DMSPd & DMSPp \\
\hline \multicolumn{4}{|l|}{ Mussels } \\
\hline \multicolumn{4}{|l|}{ Chambers with mussels } \\
\hline Before feeding & $26(19-33)$ & 0 & 0 \\
\hline Soon after feeding ended & $30(9-41)$ & 0 & 0 \\
\hline Max. after feeding ended & $71(41-111)$ & 0 & $34(19-50)$ \\
\hline $\begin{array}{l}\text { End of study: } 25 \mathrm{~h} \text { after } \\
\text { feeding ended }\end{array}$ & $47(32-68)$ & 0 & $25(0-50)$ \\
\hline \multicolumn{4}{|l|}{ Control chamber } \\
\hline Before feeding & 0 & 0 & 0 \\
\hline Soon after feeding ended & 3 & 0 & 3770 \\
\hline Max. after feeding ended & 12 & 0 & 3770 \\
\hline End of study: $25 \mathrm{~h}$ after feeding ended & 12 & 0 & $\mathrm{~nm}$ \\
\hline \multicolumn{4}{|l|}{ Scallops } \\
\hline \multicolumn{4}{|l|}{ Chambers with scallops } \\
\hline Before feeding & $2(1-2)$ & 0 & 0 \\
\hline Soon after feeding ended & $21(20-23)$ & $3(0-8)$ & $37(15-54)$ \\
\hline Max. after feeding ended & $22(21-23)$ & $16(8-22)$ & $103(72-156)$ \\
\hline $\begin{array}{l}\text { End of study: } 23.5 \mathrm{~h} \text { after } \\
\text { feeding ended }\end{array}$ & $17(10-21)$ & $6(0-19)$ & 0 \\
\hline \multicolumn{4}{|l|}{ Control chamber } \\
\hline Before feeding & 0 & 3 & 0 \\
\hline Soon after feeding ended & 20 & 3 & 4470 \\
\hline Max. after feeding ended & 23 & 20 & 4470 \\
\hline End of study: $23.5 \mathrm{~h}$ after feeding ended & 23 & 20 & $\mathrm{~nm}$ \\
\hline
\end{tabular}


have been 3770 to $4470 \mathrm{nmol}$ chamber $^{-1}$ if no ingestion had occurred, as earlier noted).

Low concentrations of DMS were measured before feeding in the water of the chambers containing bivalves of both species, although the concentration of DMS in the control chambers was 0 (below the DMS detection limit of $2 \mathrm{nmol}$ chamber $^{-1}$, see legend of Table 1) prior to the addition of algal culture, indicating that both the mussels and scallops released small quantities of DMS to the water before they were fed (Table 1). The batch of Tetraselmis sp. used in the mussel study contained little DMS; when the quantity fed was added to the chambers, it increased DMS by just 3 to $4 \mathrm{nmol} \mathrm{chamber}{ }^{-1}$ on average (Table 1). During the $25 \mathrm{~h}$ that the mussels were studied following the end of feeding, the maximum DMS concentrations observed in the 3 mussel-containing chambers averaged $71 \mathrm{nmol}^{\text {chamber }}{ }^{-1}$; although DMS in the mussel chambers increased by $41 \mathrm{nmol}$ chamber $^{-1}$ (from 30 to $71 \mathrm{nmol}^{\mathrm{chamber}}{ }^{-1}$ ) after the end of feeding, the mussel control increased by $9 \mathrm{nmol}$ chamber $^{-1}$, indicating that the mussels added at most an average of only $32 \mathrm{nmol}$ DMS chamber ${ }^{-1}$, corresponding to $0.8 \%$ of the DMSP fed. The batch of Tetraselmis sp. used in the scallop study contained enough DMS to increase the DMS concentration by 19 to $20 \mathrm{nmol}$ chamber $^{-1}$ when the quantity fed was added to the chambers (Table 1). However, no significant further increase in DMS occurred in any of the scallop chambers, indicating that the scallops did not add DMS to the ambient water following feeding.

In the mussel study, the concentration of DMS in the alkalinized filtrates used to measure the concentration of ambient DMSPd never exceeded the native DMS concentration in the filtrates, indicating that the ambient DMSPd concentration was always 0 (Table 1). In the scallop study, small amounts of DMSPd were detected $(\leq 0.5 \%$ of the DMSP fed), but the average amount of DMSPd in scallop-containing chambers never exceeded that in the control (Table 1), indicating that the scallops were not releasing DMSPd to the water.

Both the mussels and scallops started to release feces into the environment 2 to $3 \mathrm{~h}$ after feeding ended. The total amounts of released fecal DMSP accumulated during the study were similar for all 3 sets of mussels. They released 25,31 , and $50 \mathrm{nmol}$ of DMSP in feces, corresponding on average to $0.9 \%$ of the DMSP fed. The 3 sets of scallops were more divergent; they released 5 , 36 , and $400 \mathrm{nmol}$ of DMSP in feces, corresponding to $0.1,0.81$, and $8.9 \%$, i.e. an average of $3.3 \%$ of the DMSP fed. Our vacuuming procedure for removing feces from the chambers not only collected all feces but also would have collected any pseudofeces, plus most of any Tetraselmis sp. that might have settled to the bottom without being ingested. Thus, our fecal DMSP measures demonstrate that if any pseudofeces production or algal settling occurred, only small quantities of DMSP could have been involved.

Within each species, the fed and unfed bivalves dissected for tissue analysis were similar in size (Table 2). Although our assay method for tissue samples did not distinguish DMSP and DMS, we refer to the tissue material as being simply DMSP for simplicity and, more importantly, because most of the material was probably DMSP rather than DMS (Iida \& Tokunaga 1986).

The gastrointestinal tissue (digestive glands) of fed mussels contained, on average, $0.72 \mu \mathrm{mol}$ individual $^{-1}$ more DMSP than that of unfed mussels (Table 3). Because the amount of algal DMSP supplied to the fed mussels was almost exactly the same, $0.75 \mu \mathrm{mol}$ individual $^{-1}$, one might conclude that virtually all ingested DMSP remained in the gastrointestinal tissue at the end of our $25 \mathrm{~h}$ study. For 2 reasons, however, we are not convinced that the ingested DMSP can be localized to the gastrointestinal tissue. First, the total-tissue DMSP in the fed mussels, which averaged $2.1 \mu \mathrm{mol}$ individual ${ }^{-1}$ higher than in the unfed mussels (Table 3 ), was far greater than could be accounted for by the algal DMSP with which the mussels were fed, suggesting that the fed mussels had higher DMSP for reasons other than feeding. Second, the statistical distribution of tissue DMSP was in some cases dramatically nonnormal. Two mussels in the fed group (one each in Chambers A and B) had total-tissue DMSP levels of 25.8 and $14.2 \mu \mathrm{mol}$ individual ${ }^{-1}$, so high as to be far outside the range of most individuals. With the 2 extreme individuals present, the statistical distribution

Table 2. Mytilus edulis and Argopecten irradians. Mean (range) wet wt of all fleshy tissue, of gastrointestinal tissue, and of tissue other than the separately assayed gastrointestinal tissue in fed and unfed individuals subjected to tissue analysis. n: no. of individuals studied. No statistically significant differences existed between fed and unfed groups in any category of tissue (Mann-Whitney $U$-test, $M$. edulis, $\mathrm{p}>0.3, A$. irradians, $\mathrm{p}>0.3$ )

\begin{tabular}{|c|c|c|c|}
\hline \multirow{2}{*}{ Bivalves (n) } & \multicolumn{3}{|c|}{ Weight of fleshy tissue $\left(\mathrm{g}\right.$ ind $^{-1}$ ) } \\
\hline & All & Gastrointestinal & Other \\
\hline \multicolumn{4}{|l|}{ Mussels } \\
\hline Fed (15) & $8.3(4.9-14.5)$ & $1.16(0.81-2.32)$ & $7.1(4.0-12.2)$ \\
\hline Unfed (5) & $8.6(5.9-15.0)$ & $1.19(0.82-2.30)$ & $7.4(5.1-12.7)$ \\
\hline \multicolumn{4}{|l|}{ Scallops } \\
\hline Fed (6) & $10.9(8.4-13.6)$ & $1.81(1.2-2.4)$ & $9.1(7.1-11.2)$ \\
\hline Unfed (6) & $10.0(7.9-12.4)$ & $1.55(1.2-2.0)$ & $8.4(6.7-10.4)$ \\
\hline
\end{tabular}


Table 3. Mytilus edulis and Argopecten irradians. Mean (range) of DMSP in all fleshy tissue, in gastrointestinal tissue, and in tissue other than the separately assayed gastrointestinal tissue in individuals fed DMSP-containing Tetraselmis sp. and in unfed individuals. n: no. of individuals measured. Means for fed mussels are of limited interpretive value because of nonnormality

\begin{tabular}{|c|c|c|c|}
\hline \multirow[t]{2}{*}{ Bivalves (n) } & \multicolumn{3}{|c|}{ DMSP $\left(\mu \mathrm{mol}\right.$ ind.$\left.^{-1}\right)$} \\
\hline & All & Gastrointestinal & Other \\
\hline \multicolumn{4}{|l|}{ Mussels fed } \\
\hline Chamber A (5) & $7.4(1.3-25.8)$ & $1.18(0.2-4.5)$ & $6.2(1.0-21.3)$ \\
\hline Chamber B (5) & $6.3(3.5-14.2)$ & $1.18(0.3-3.8)$ & $5.1(3.2-10.3)$ \\
\hline Chamber C (5) & $3.9(2.2-5.5)$ & $0.53(0.2-0.9)$ & $3.4(1.5-4.9)$ \\
\hline All (15) & $5.9(1.3-25.8)$ & $0.96(0.2-4.5)$ & $4.9(1.0-21.3)$ \\
\hline Mussels unfed (5) & $3.8(1.5-8.4)$ & $0.24(0.1-0.7)$ & $3.6(1.4-7.8)$ \\
\hline \multicolumn{4}{|l|}{ Scallops fed } \\
\hline Chamber A (2) & $4.0(3.4-4.5)$ & $0.99(0.7-1.2)$ & $3.0(2.2-3.8)$ \\
\hline Chamber B (2) & $2.8(0.6-5.0)$ & $0.99(0.2-1.7)$ & $1.8(0.4-3.2)$ \\
\hline Chamber C (2) & $2.2(0.9-3.6)$ & $0.57(0.2-0.9)$ & $1.7(0.7-2.7)$ \\
\hline All (6) & $3.0(0.6-5.0)$ & $0.85(0.2-1.7)$ & $2.2(0.4-3.8)$ \\
\hline Scallops unfed (6) & $2.9(1.1-5.0)$ & $0.25(0.1-0.5)$ & $2.6(0.9-4.7)$ \\
\hline
\end{tabular}

the 2 extreme individuals in the fed group cannot be simply ignored as outliers. The high levels of DMSP in those 2 individuals, however, cannot be accounted for by the algal DMSP with which they were fed, even if we presume they had ingested all the algal DMSP (3.8 $\mu \mathrm{mol}$ chamber $^{-1}$ ) added to their chambers; this indicates that these individuals had unusual tissue DMSP levels before our study began. If, as a theoretical exercise, we treat the extreme individuals as outliers and remove their data, the average totaltissue DMSP in the fed mussels falls to $3.7 \mu \mathrm{mol}$ individual ${ }^{-1}$, almost identical to that of unfed mussels (Table 3). Moreover, the average DMSP in the gastrointestinal tissue of the fed group falls to $0.47 \mu \mathrm{mol}$ individual ${ }^{-1}$, and that in the other tissue to $3.2 \mu \mathrm{mol}$ individ$\mathrm{ual}^{-1}$, values close to those in the unfed

of DMSP concentration in the fed mussels was dramatically non-normal (Figs. 1 \& 2) whether we examined all tissues taken together (Shapiro-Wilk $W$-test, $W=$ 0.66, $\mathrm{p}=0.00009)$, the gastrointestinal tissue alone ( $W=0.61, \mathrm{p}=0.00003)$, or tissues other than the separately assayed gastrointestinal tissue $(W=0.71, \mathrm{p}=$ 0.0004). For carrying out mass balance calculations,

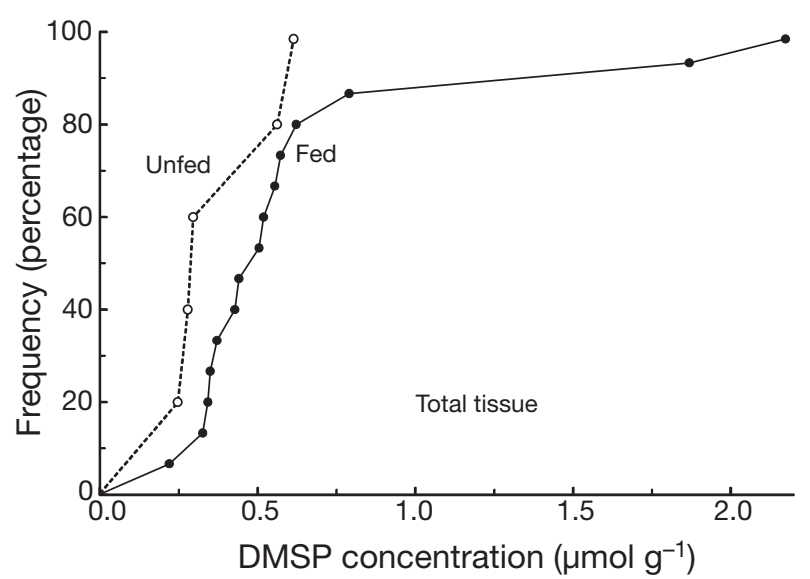

Fig. 1. Mytilus edulis. Cumulative frequency distribution of tissue dimethylsulfoniopropionate (DMSP) concentration (DMSP g ${ }^{-1}$ wet wt) in all fleshy tissue combined in (•) 15 mussels fed Tetraselmis sp., a DMSP-containing alga and (O) 5 unfed mussels. Each data point = DMSP concentration in 1 individual. Distributions for tissue other than the separately assayed gastrointestinal tissue in fed and unfed mussels closely resembled those shown here for total tissue. In this type of plot, normally distributed data assume a sigmoid shape, with inflexion point (frequency $=50 \%$ ) at the midpoint of spread of data on $x$-axis group. In all, the data do not provide convincing evidence that the algal DMSP we fed was localized in tissue of the mussels after $25 \mathrm{~h}$.

In the scallops studied, no individuals were dramatically different from the others with regard to their DMSP levels, and for the most part the distributions of the values were statistically normal (Shapiro-Wilk $W$-test, $\mathrm{p}=0.05$ to 0.50 ). In all 3 fed chambers (Table 3 ), the amount of DMSP in the scallop gastrointestinal tissue was distinctly higher than the corresponding amount in unfed scallops, making a case for localization of ingested DMSP in the gastrointestinal tissue $23.5 \mathrm{~h}$ after feeding ended. The case is weak, however,

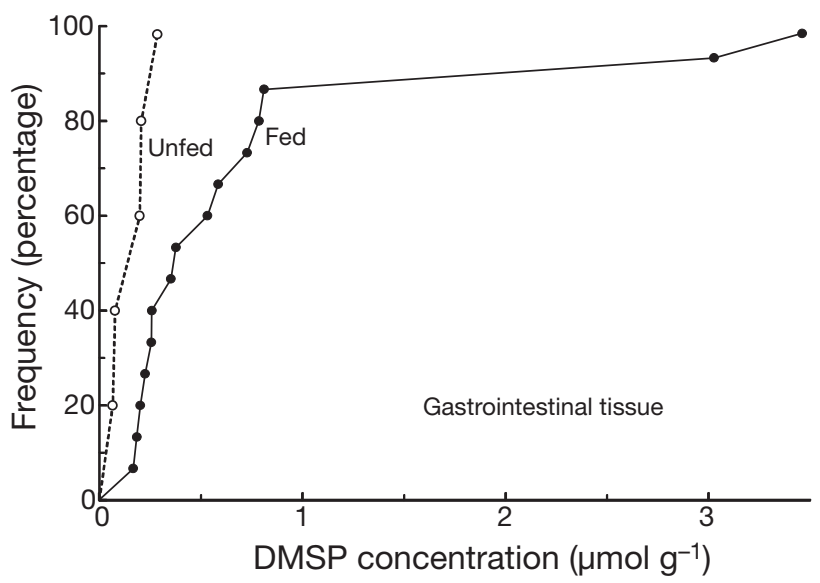

Fig. 2. Mytilus edulis. Cumulative frequency distribution of tissue DMSP concentration (DMSP $\mathrm{g}^{-1}$ wet wt) in gastrointestinal tissue (digestive gland) of the same individuals shown in Fig. 1. Each data point = DMSP concentration in 1 individual 
because the 6 fed scallops taken as a group did not differ to a statistically significant extent from the 6 unfed scallops (Mann-Whitney $U$-test, $\mathrm{p}=0.11$ : a parametric test could not be used because variance was higher in the fed group). Moreover, the average DMSP content of the gastrointestinal tissue in the fed scallops, being $0.6 \mu \mathrm{mol}$ DMSP individual ${ }^{-1}$ higher than that in the unfed scallops, corresponded to only $27 \%$ of the DMSP fed $\left(2.2 \mu \mathrm{mol}\right.$ individual $\left.^{-1}\right)$. The remainder of the ingested DMSP cannot have been localized in tissue other than the gastrointestinal tissue, because the measured DMSP in the other tissue was actually on average lower in fed than in unfed scallops (Table 3). Another troubling result for mass balance purposes was that total-tissue DMSP was almost identical in fed and unfed scallops.

To learn more about the distribution of DMSP in various subparts of bivalve non-gastrointestinal tissue, we separately analyzed the gill, mantle (including gonad), and foot in 8 mussels, and the gill, mantle, and adductor muscle in 4 scallops. DMSP was found in all types of tissue and was especially concentrated in the mussel mantle (Table 4).

\section{DISCUSSION}

Our most salient result is that phytoplanktivory by mussels Mytilus edulis and scallops Argopecten irradians does not accelerate the conversion of algal DMSP to ambient DMS during the $24 \mathrm{~h}$ following feeding (Table 1), at least when the bivalves are feeding on Tetraselmis sp. Strain UW474 (a strain of unknown DMSP lyase status). The near-zero accumulation of DMS in the study chambers indicates that there was little DMS production, because we know from our tests with reagent DMS that DMS persisted when added to the water in the chambers. The failure of bivalve phytoplanktivory to accelerate the formation of ambient DMS is consistent with the 'sloppy feeding' hypothesis for acceleration of DMS production by copepod and krill grazing. As argued by Kasamatsu et al. (2004) and others, if break-up and incomplete ingestion of phytoplankton cells during feeding are

Table 4. Mytilus edulis and Argopecten irradians. Mean (range) concentration of DMSP relative to wet wt in 3 tissues. Muscle analyzed was foot in mussels and adductor muscle in scallops. n: no. of individuals studied

\begin{tabular}{|lccc|}
\hline \multirow{2}{*}{ Bivalves (n) } & \multicolumn{3}{c|}{ DMSP $\left(\mathrm{nmol} \mathrm{g}^{-1}\right)$} \\
\cline { 2 - 4 } & Gill & Mantle & Muscle \\
\hline Mussels (8) & $33(5-140)$ & $900(47-2900)$ & $67(8-190)$ \\
Scallops (4) & $72(29-100)$ & $31(11-57)$ & $110(62-170)$ \\
\hline
\end{tabular}

instrumental in the prompt acceleration of DMS production by grazing, phytoplanktivores that ingest algal cells whole (such as bivalves) would not be expected to accelerate DMS production, except possibly in ways long-delayed after feeding.

As argued in the 'Introduction', mussels or other bivalves may ingest large fractions of local algal DMSP production in ecological settings in which their populations are dense (Newell 1988, Jørgensen 1990, Riisgård 1991, Heip et al. 1995, Dame 1996). Our results show that in these types of settings, bivalve populations probably strongly reduce rates of production of ambient DMS in the short term. The bivalves themselves essentially produce no ambient DMS from the algal DMSP they ingest during the first $24 \mathrm{~h}$ following feeding. Simultaneously, they remove phytoplankton that otherwise might have been subjected to processes that accelerate ambient DMS formation from algal DMSP, such as grazing by small zooplankton (Dacey \& Wakeham 1986, Archer et al. 2003, Lee et al. 2003). The bivalves also seem likely to slow short-term DMS production by reducing populations of small zooplankton, based on the emerging paradigm that bivalves are significant zooplankton consumers (Lehane \& Davenport 2002, Wong \& Levinton 2006).

Based on assays of DMSP and DMS, an apt description of the fate of algal DMSP ingested by bivalves is that, during the $24 \mathrm{~h}$ following feeding, it disappears from their environment: almost none can be found as DMS, DMSPd, or DMSPp in the ambient water, or in feces. The mussels in our study added some DMS and DMSPp to the ambient water in the hours following feeding (Table 1) and eliminated some DMSP in feces, but the total of all outputs represented just 2 to $3 \%$ of the algal DMSP ingested. The scallops, although they added nothing in net fashion to the ambient water (Table 1), eliminated more DMSP in feces than the mussels on average, but the total of their outputs was only about $3 \%$ of the DMSP ingested. In these respects, mussels and scallops are unique among the animal phytoplanktivores thus far investigated. Menhaden, although they produce almost no ambient DMS, release considerable DMSPd and fecal DMSP in the $24 \mathrm{~h}$ after feeding (Hill \& Dacey 2006). Salps, while apparently not releasing DMS or DMSPd, excrete unbroken algal cells back into the environment in feces within $24 \mathrm{~h}$ (Kasamatsu et al. 2004). Only the bivalves essentially fail to release any DMSP or DMS back into their environments after DMSP ingestion (although in principle they might release DMSP derivatives [e.g. demethylated products; Tang et al. 2000a] not measured in the present study and not typically measured in other studies of animal phytoplanktivory).

The DMSP ingested by the bivalves in our study seems most likely to have been in their bodies $24 \mathrm{~h}$ 
after the end of feeding. We obtained weak evidence of accumulation of ca. $30 \%$ of ingested DMSP in the gastrointestinal tissue of the scallops. We were unsuccessful, however, in documenting accumulation in the mussels because of the high and non-normal variation among individuals in their naturally occurring content of tissue DMSP. Similar variation has been observed in other populations of Mytilus edulis (Hill et al. 1995). A priori, a simple expedient for studies like the present one would seem to be to allow mussels to void tissue DMSP prior to investigation; however, we have found that some individuals exhibit high tissue DMSP levels even after 5 wk of dietary DMSP deprivation (Hill et al. 1995). The fact that we were unable to document the accumulation of most ingested DMSP in the tissue of the mussels leaves open the possibility that considerable DMSP might have been transformed to nonDMSP/non-DMS products. The unusual statistical distributions provide a more parsimonious explanation in our opinion, however.

Tang et al. (2000a) discussed the chemical forms in which DMSP accumulated in animal tissue might ultimately be lost; they demonstrated that in the copepod Temora longicornis, tissue DMSP primarily returns to the environment as DMSPd. From evidence we have (authors' pers. obs.), populations of Mytilus edulis on average lose about half their tissue DMSP over the course of $35 \mathrm{~d}$ of dietary DMSP deprivation (some individuals lose none, but others lose most). If the lost tissue DMSP enters the ambient water as DMSPd (available for microbial breakdown to DMS) or as DMS, it might contribute to DMS outgassing to the atmosphere. An important local role of bivalve populations might, therefore, be to smooth the rate at which DMS outgases: during a bloom of DMSP-containing phytoplankton, bivalves might take up the DMSP promptly (preventing access to it by zooplankton [or viruses, etc.] which would cause quick conversion to DMS), but thereafter they might mediate slow production of ambient DMS from the DMSP.

Acknowledgements. J. Burnett, D. Hill, S. Hill, D. Kulis, and D. Leavitt made essential contributions. Others to whom thanks are due for invaluable assistance are M. Dennett, D. Franks, L. Hare, B. Lancaster, R. Lewin, J. McDowell, D. Radosh, S. Shumway, G. Wikfors, and several reviewers. Financial support came from Michigan State University (R.W.H. sabbatical) and the US National Science Foundation, grants OCE-9411497 and OCE-9102532.

\section{LITERATURE CITED}

Andreae MO, Crutzen PJ (1997) Atmospheric aerosols: biogeochemical sources and role in atmospheric chemistry. Science 276:1052-1058

Archer SD, Stelfox-Widdicombe CE, Malin G, Burkill PH (2003) Is dimethyl sulfide production related to microzoo- plankton herbivory in the southern North Sea? J Plankton Res 25:235-242

Asmus H, Asmus RM (1993) Phytoplankton-mussel bed interactions in intertidal ecosystems. In: Dame RF (ed) Bivalve filter feeders, Springer-Verlag, New York, p 57-84

Bates TS, Lamb, BK, Guenther A, Dignon J, Stoiber RE (1992) Sulfur emissions to the atmosphere from natural sources. J Atmos Chem 14:315-337

Bayne BL, Thompson RJ, Widdows J (1973) Some effects of temperature and food on the rate of oxygen consumption by Mytilus edulis. In: Wieser W (ed) Effects of temperature on ectothermic organisms. Springer-Verlag, New York, p 181-193

Bricelj VM, Epp J, Malouf RE (1987) Comparative physiology of young and old cohorts of bay scallop Argopecten irradians irradians (Lamarck): mortality, growth, and oxygen consumption. J Exp Mar Biol Ecol 112:73-91

Chipman WA, Hopkins JG (1954) Water filtration by the bay scallop, Pecten irradians, as observed with the use of radioactive plankton. Biol Bull (Woods Hole) 107:80-91

Dacey JWH, Blough NV (1987) Hydroxide decomposition of dimethylsulfoniopropionate to form dimethylsulfide. Geophys Res Lett 14:1246-1249

Dacey JWH, Wakeham SG (1986) Oceanic dimethylsulfide: production during zooplankton grazing on phytoplankton. Science 233:1314-1316

Daly KL, DiTullio GR (1996) Particulate dimethylsulfoniopropionate removal and dimethylsulfide production by zooplankton in the Southern Ocean. In: Kiene RP, Visscher PT, Keller MD, Kirst GO (eds) Biological and environmental chemistry of DMSP and related sulfonium compounds. Plenum, New York, p 223-238

Dame RF (1996) Ecology of marine bivalves. CRC Press, Boca Raton, FL

Gosling E (2003) Bivalve molluscs. Biology, ecology and culture. Fishing News Books, Malden, MA

Heip CHR, Goosen NK, Herman PMJ, Kromkamp J, Middelburg JJ, Soetaert K (1995) Production and consumption of biological particles in temperate tidal estuaries. Oceanogr Mar Biol Annu Rev 33:1-149

Hill RW, Dacey JWH (2006) Metabolism of dimethylsulfoniopropionate (DMSP) by juvenile Atlantic menhaden Brevoortia tyrannus. Mar Ecol Prog Ser 322:239-248

Hill RW, Dacey JWH, Hill DKD, McDowell JE, Leavitt DF (1995) Accumulation and retention of dimethylsulfoniopropionate by bivalve molluscs: high and nonnormal variation. Biol Bull (Woods Hole) 189:233-234

Hill RW, White BA, Cottrell MT, Dacey JWH (1998) Virusmediated total release of dimethylsulfoniopropionate from marine phytoplankton: a potential climate process. Aquat Microb Ecol 14:1-6

Iida H, Tokunaga T (1986) Dimethyl sulfide and dimethyl- $\beta$ propiothetin in shellfish. Bull Jpn Soc Sci Fish 52:557-563

Iverson RL, Nearhoof FL, Andreae MO (1989) Production of dimethylsulfonium propionate and dimethylsulfide by phytoplankton in estuarine and coastal waters. Limnol Oceanogr 34:53-67

Jørgensen CB (1990) Bivalve filter feeding. Olsen \& Olsen, Fredensborg

Kasamatsu N, Kawaguchi S, Watanabe S, Odate T, Fukuchi M (2004) Possible impacts of zooplankton grazing on dimethylsulfide production in the Antarctic Ocean. Can J Fish Aquat Sci 61:736-743

Keller MD, Bellows WK, Guillard RRL (1989) Dimethyl sulfide production in marine phytoplankton. In: Saltzman ES, Cooper WJ (eds) Biogenic sulfur in the environment. American Chemical Society, Washington, DC, p 167-182 
Leck C, Larsson U, Bågander LE, Johansson S, Hajdu S (1990) Dimethyl sulfide in the Baltic Sea: annual variability in relation to biological activity. J Geophys Res 95: 3353-3363

Lee PA, Saunders PA, de Mora SJ, Deibel D, Levasseur M (2003) Influence of copepod grazing on concentrations of dissolved dimethylsulfoxide and related sulfur compounds in the North Water, northern Baffin Bay. Mar Ecol Prog Ser 255:235-248

Lehane C, Davenport J (2002) Ingestion of mesozooplankton by three species of bivalve: Mytilus edulis, Cerastoderma edule, and Aequipecten opercularis. J Mar Biol Assoc 82: 615-619

Malin G, Kirst GO (1997) Algal production of dimethyl sulfide and its atmospheric role. J Phycol 33:889-896

Møhlenberg F, Riisgård HU (1979) Filtration rate, using a new indirect technique, in thirteen species of suspension-feeding bivalves. Mar Biol 54:143-147

Newell RIE (1988) Ecological changes in Chesapeake Bay: are they the result of overharvesting the American oyster, Crassostrea virginica? In: Lynch MP, Krome EC (eds) Understanding the estuary (Chesapeake Research Consortium Publ 129). Chesapeake Bay Institute, Johns Hopkins University, Baltimore, MD, p 536-546

Palmer RE, Williams LG (1980) Effect of particle concentration on filtration efficiency of the bay scallop Argopecten irradians and the oyster Crassostrea virginica. Ophelia 19: 163-174

Peirson WM (1983) Utilization of eight algal species by the bay scallop, Argopecten irradians concentricus (Say). J Exp Mar Biol Ecol 68:1-11

Petersen JK, Bougrier S, Smaal AC, Garen P, Robert S, Larsen JEN, Brummelhuis E (2004) Intercalibration of mussel Mytilus edulis clearance rate measurements. Mar Ecol Prog Ser 267:187-194

Riisgård HU (1991) Filtration rate and growth in the blue mus-

Editorial responsibility: Howard Browman (Associate Editorin-Chief), Storebø, Norway sel (Mytilus edulis Linnaeus, 1758): dependence on algal concentrations. J Shellfish Res 10:29-35

Riisgård HU (2001) On measurement of filtration rates in bivalves - the stony road to reliable data: review and interpretation. Mar Ecol Prog Ser 211:275-291

Riisgård HU, Møhlenberg F (1979) An improved automatic recording apparatus for determining the filtration rate in Mytilus edulis as a function of size and algal concentration. Mar Biol 52:61-67

Shumway SE (ed) (1991) Scallops: biology, ecology and aquaculture. Elsevier, New York

Strömgren T, Cary C (1984) Growth in length of Mytilus edulis L. fed on different algal diets. J Exp Mar Biol Ecol 76:23-34

Tang KW, Fenn TD, Visscher PT, Dam HG (2000a) Regulation of body dimethylsulfoniopropionate (DMSP) content by the copepod Temora longicornis: a test of four mechanisms. Mar Biol 136:749-757

Tang KW, Rogers DR, Dam HG, Visscher PT (2000b) Seasonal distribution of DMSP among seston, dissolved matter and zooplankton along a transect in the Long Island Sound estuary. Mar Ecol Prog Ser 206:1-11

Widdows J (1973) The effects of temperature on the metabolism and activity of Mytilus edulis. Neth J Sea Res 7: 387-398

Winter JE (1978) A review on the knowledge of suspension feeding in lamellibranchiate bivalves, with special reference to artificial aquaculture systems. Aquaculture 13: $1-33$

Wong WH, Levinton JS (2006) The trophic linkage between zooplankton and benthic suspension feeders: direct evidence from analyses of bivalve faecal pellets. Mar Biol 148:799-805

Yoch D (2002) Dimethylsulfoniopropionate: its sources, role in the marine food web, and biological degradation to dimethylsulfide. Appl Environ Microbiol 68:5804-5815

Submitted: May 8, 2006; Accepted: November 30, 2006 Proofs received from author(s): July 24, 2007 